\title{
Execution of Fiduciary Collateral Based on the Decision of the Constitutional Court Number 18/PUU-XVII/2019
}

\author{
Sofyan Wimbo Agung Pradnyawan'1, Siti Syahida Nurani², Arief Budiono3, Sasongko" \\ ${ }^{1}$ Universitas PGRI Madiun, \\ 2Universitas Muhammadiyah Kupang, \\ ${ }^{3}$ Universitas PGRI Madiun, \\ 4Universitas PGRI Madiun \\ * Correspondence email: sofyannusantara@gmail.com
}

\begin{abstract}
The Constitutional Court responded to the existence of a debt collector who had been very unsettling by the Constitutional Court by issuing Decision Number 18/PUU-XVII/2019 dated January 6, 2020. Based on the request for a judicial review of Law 42/1999 submitted by husband and wife Apriliani Dewi and Suri Agung Prabowo . Apriliani is a fiduciary who experiences direct losses as a result of creditors' withdrawal of the object of fiduciary security in the form of a car. Both applicants are declared to have legal standing in submitting a request for a judicial review. The Constitutional Court granted it with Decision Number 18/PUU-XVII/2019. In this decision, the execution mechanism for the fiduciary guarantee object was changed by the Constitutional Court as long as it was not provided voluntarily by the debtor. Previously, the Fiduciary Law allowed creditors to execute the object of fiduciary collateral themselves, but now to carry out the execution, creditors must submit an application to the District Court. However, the implementation of direct execution by the creditor without going through the District Court can be done if the debtor admits that there is a default or default in his agreement with the creditor.
\end{abstract}

KEYWORDS : Execution, Fiduciary, Constitutional Court

\section{INTRODUCTION}

Indonesia's economic growth in 2019 is above the average world economic growth. Economic growth of 5.02\% was booked in the third quarter of 2019. This was stated by Minister of Finance Sri Mulyani Indrawati. Improving economic growth is often followed by an increasing pattern or lifestyle of the community (Vera, 2020). Meeting a person's needs often cannot be fulfilled alone but requires help from other parties. So it is not uncommon to meet these needs with accounts payable.

The lifestyle of individuals today has a tendency towards consumption. The tendency of a consumptive lifestyle has also been triggered by the proliferation of information technology which is increasingly developing and easy to access. One of them is with the proliferation of financial institution advertisements which are increasingly mushrooming by means of promotion through social media and other internet media (Ade, 2009). 
In Indonesia, two financial institutions, namely financial institutions and banks, provide consumer finance, leasing, and factoring. They generally use contract procedures that include fiduciary security for objects of fiduciary security. Leasing is a new financing alternative. The offer of convenience provided by leasing, both the process and the requirements, often attracts entrepreneurs and individuals to support their activities, so that they choose leasing as a source of financing (Nahrowi, 2013).

For entrepreneurs, one of the efforts to develop a business can be done by adding company assets, which of course requires a large amount of funding. To meet these funding needs, the company chooses external or external funding. One way to fulfill it is through leasing. In leasing (leasing), the party who finances the provision of capital goods is called the Lessor, while the party who will use the goods to be leased and is the owner of the goods economically and is responsible for the goods is called Lessee (Nining, 2010).

Lessee usually those who choose the capital goods needed and who place orders, inspect and maintain those related to the operation of these goods. Leasing was known in Indonesia in 1974 through a Joint Decree of 3 Ministers, namely: the Minister of Finance, the Minister of Trade, and the Minister of Industry.

According to the Joint Decree of the Minister of Finance and the Minister of Trade and Industry of the Republic of Indonesia, No. KEP-122/MK/IV/2/1974, Number 32/M/SK/2/1974, and Number 30/Kpb/I/1974 dated February 7, 1974. Stating that leasing is any activity of company financing in the context of providing capital goods which is used by the company within a certain period of time, based on periodic payments accompanied by the right to vote for the company to buy the capital goods concerned or to extend the lease period based on the residual value of money that has been mutually agreed upon. Minister of Finance No.1169/KMK.01/1991 dated September 21, 1991 concerning leasing activities is a company financing activity in the form of providing capital goods, either by lease with option rights (finance lease) or leasing without rights option (operating lease), to be used by the lessee for a certain period based on periodic payments (Khotibul, 2010).

A popular example is financing in the automotive sector. In this case, the supplier collaborates with various companies or financing institutions, so that the sales of vehicle units can be maintained, and benefit consumers because vehicle receipts can be processed quickly. The leasing or leasing company will make cash payments to suppliers. Leasing companies always try to find potential customers, who have been adjusted to the conditions that have been set.

Usually, companies in the automotive sector carry out this cooperation in terms of sales on credit or it can be said that distributors or dealers take advantage of the facilities from the leasing company. Sales made on credit will be submitted to the Lessor, then from the object by the Lessor will pay cash to the distributor or dealer, and then the Lessee pays the rent periodically to the Lessor during the lease period which entirely includes the return of the amount financed and interest thereon.

In its implementation, debtors often neglect their obligations. To overcome this problem, the method most often used by creditors is to use debt collector services. The existence of debt collectors to collect credit often worries debtors. The Constitutional Court responded to the existence of a debt collector who had been very unsettling by the 
Constitutional Court by issuing Decision Number 18/PUU-XVII/2019 dated January 6, 2020.

The decision is that the execution mechanism for the object of fiduciary security is amended by the Constitutional Court as long as it is not provided voluntarily by the debtor. Previously, the Fiduciary Law allowed creditors to execute the object of fiduciary collateral themselves, but now to carry out the execution, creditors must submit an application to the District Court. However, the implementation of direct execution by the creditor without going through the PN can be done if the debtor admits that there is a default or default in his agreement with the creditor (Joni, 202). Based on the above background, the formulation of the problem is how to analyze the law on the Constitutional Court decision No. Decision Number 18/PUU-XVII/2019.

\section{METHODOLOGY}

This study uses a normative juridical approach. The normative juridical approach is an approach which is carried out based on the main legal materials by examining theories, concepts, legal principles and laws and regulations related to this research. This approach is also known as the literature approach, namely by studying books, laws and regulations and other documents related to this research.

\section{RESULTS AND DISCUSSION}

Reviewing the repertoire of civil law there are a number of instruments that are used as collateral/collateral. Where each of these instruments has its own characteristics. All of these can be classified under different objects. Such as guarantees for movable objects, immovable objects, tangible objects, intangible objects, objects whose rights lie with the right owner or are handed over to the recipient vis versa. Among the guarantees are lien, mortgage, creditverband, mortgage, and fiduciary. Initially this fiduciary issue was considered an illegal pawn.

The concepts of pawning and fiduciary are similar but not similar because in the pawning the control of the goods used as the object of the pledge lies with the creditor, while in fiduciary, the fiduciary continues to control and receive benefits from the difference which becomes the object of fiduciary security. The fiduciary institution for the Indonesian nation is not a new institution. For a long time, the Indonesian people have known this guarantee institution. In fact, in the explanation of the Fiduciary Law it is said that fiduciary institutions have been recognized since the Dutch colonial era. The difference is that the well-known fiduciary institutions are based on jurisprudence. The jurisdiction was related to the case in 1932 in the HGH arrest for the BPM Clignet case during the Dutch East Indies era. Then finally in the decision of the Supreme Court Number 372 K/Sip/1970 dated September 1, 1971 and the Agun Court Decision of the Republic of Indonesia Number 227K/Sip/1977 dated February 2, 1980 (Sunaryo, 2007).

The fiduciary institutions that have been used have been simple, easy, and fast, but on the other hand, they are deemed as not guaranteeing legal certainty. This is because the fiduciary institution regulation provides a loophole to be interpreted differently from one party to another. Such provisions in the end create legal uncertainty which in turn can harm the parties (Shavira, 2017). In fact, as quoted by Gustav Radbruch as quoted by 
Isnaeni, the objective of law consists of 3 (three) elements, namely legal certainty, justice and benefit. How is it possible for a legal rule to provide benefits and justice when the legal rule does not provide legal certainty in its enforcement (Isnaeni, 2017).

The guarantee itself is something that is used as a liability in the form of a money loan. According to the Indonesian Dictionary, Guarantee means something that is given to a creditor to create confidence that the debtor will fulfill obligations that can be valued in money arising from an engagement. In line with what was agreed upon in the seminar of the National Legal Development Agency in Yogyakarta in 1977 which defines Guarantee is to guarantee the fulfillment of obligations that can be valued in money arising from a legal engagement4. Guarantee law is a popular field of law, especially in economic and business law. (The economic law, wiertschafrecht, or droit econonique) (Aprilianti, 2011).

Guarantee law has the function of supporting economic progress and development progress in general. Because guarantees provide opportunities for economic development and growth when the parties have limited access to resources (capital) in developing their economic activities. With something that can be used as a guarantee, it gives the debtor the opportunity to obtain other beneficial rights in order to develop economic activities or meet other economic needs.

Financing is the same as consumer credit, the difference is the institutions that finance it. Consumer financing is a fee provided by a financing company, while consumer credit is given by a bank.1 Whereas Article 15 of Law No.42 of 1999 concerning Fiduciary Guarantee, in essence, if the consumer (debtor) is unable to pay then finance is provided power to take the vehicle anywhere and anytime which is then signed by the consumer (Soedewi, 2005).

We know financial institutions, namely as business entities that carry out financing activities in the form of providing funds or capital goods. The Financing Institution is a non-banking alternative financing that is more adaptable to the real needs of the business community. In taking a motorized vehicle, if there is already a fiduciary agreement, then a notary deed is made that clearly in this case the finance has fulfilled the regulations in vehicle withdrawal. But in reality, most of the finance parties do not comply with these rules, such as not including fiduciary guarantees, and some are even suspected of being fake in taking the vehicle (Yahya, 2005).

There are several execution mechanisms according to the Fiducia Law. Execution is the confiscation and sale of objects that are the object of fiduciary security. Execution arises because the debtor fails to promise or does not fulfill his performance on time to the creditor. The execution of guarantees is regulated in Article 29 to Article 34 of Law No. 42 of 1999 concerning Fiduciary Security (Jatmiko, 2015):

1. The execution of the executorial title by the fiduciary recipient, namely the same power of execution as a court decision that has obtained permanent legal force;

2. Sale of objects that are the object of fiduciary security or the power of the recipient of the fiduciary itself through a public auction

3. Underhand sales made under the agreement of the fiduciary giver and recipient.

Meanwhile, according to Munir Fuady there are 5 (five) types of execution of fiduciary guarantees apart from 3 (three), namely as follows (Munir, 2013):

1. Fiduciary execution by own auction without going through the auction office;

2. Fiduciary execution by claim; 
3. Fiduciary execution of tradable goods and securities that can be traded;

4. Fiduciary execution through ordinary lawsuit;

5. Fiduciary execution according to Law No. 16 of 1985 on Flats.

Implicitly, the Fiduciary Guarantee Act regulates the institution of parate executions. Its basis is Article 15 paragraph (1), paragraph (2) and paragraph (3). Which provides freedom of action or executoriale title which gives rise to an executorial provision of a forced force (Sugianto, 2015). With the procedure after the head of the district court receives a request from the creditor as the holder of the fiduciary guarantee, the head of the district court first calls the debtor to notify and warn (aanmaning) (Yasir, 2016).

The auction process for the holder of the fiduciary guarantee as a guarantee will be sold by auction.43 Meanwhile, Article 15 paragraph (3) of the Fiduciary Security Law states "if the debtor is in default, the fiduciary recipient has the right to sell the object which is the object of fiduciary security on his own power". The execution procedure as referred to in Article 15 paragraph (3) of the Fiduciary Guarantee Law, creditors only need to submit an application for auction to the state auction office. The authority does not come from the giver of the fiduciary guarantee object but there is an equivalent according to the law itself that gives it to it.

Based on the Constitutional Court Decision issued based on the petition for a judicial review of Article 15 Paragraph (2) and Paragraph (3) 1 of Law No. 42/19991 were submitted by two applicants, namely: Apriliani Dewi and Suri Agung Prabowo (husband of Apriliani Dewi). They both became victims of arbitrary actions by debt collectors who were given the task by the Fiduciary to retrieve goods under control without going through the correct legal procedures (Arya, 2020).

Regarding this act of arbitrariness the South Jakarta District Court issued Decision Number 345/PDT.G/2018/PN.Jkt. The cell that determines that the Creditor and Debt Collector is declared to have committed illegal acts and punishes the creditor and debt collector jointly and severally to pay material and immaterial losses to the plaintiff (debtor). However, the main problem, and which ultimately prompted the applicant to apply for a judicial review, was the action of the creditor who on January 11, 2019 continued to withdraw the object of the Fiduciary Guarantee, on the basis that the Fiduciary Agreement was deemed to have permanent legal force based on the provisions of Article 15 Paragraph (2) and Paragraph (3) 1 of Law no. 42/1999.

Based on Law No. 42 of 1999 concerning the Fiduciary Guarantee, the existence of the right to execute or the power of execution is the execution of executions that can be carried out directly without going through a court and is final and binds the parties to implement the decision. Of course, regarding these rules, many people do not know and only give up if business actors or debt collectors take their vehicles by force. On the other hand, Law No. 8 of 1999 concerning Consumer Protection, states that consumers have the right to legal protection in the event of breach of promises made by business actors in this case for forced taking of consumer vehicles that have not matured (Arya, 2020).

Regarding this problem, the form of consumer protection for the execution of vehicles that are not yet due is regulated based on Law No. 8 of 1999 concerning Protection of the Parliament. That Consumers are protected by the provisions of Law no. 8 of 1999 concerning Consumer Protection. The government has a duty to foster and supervise consumer protection, regarding the withdrawal of motorized vehicles suspected 
of violating the legal rules governing the Fiduciary Guarantee Law and the Minister of Finance Regulation (Agus, 2014).

Petitioners named Aprilliani Dewi and Suri Agung Prabowo meet the legal standing requirements in the Constitutional Court Law. The articles being tested are Article 15 paragraph (2) and paragraph (3) of Law Number 42 of 1999 concerning Fiduciary Guarantee of Articles in the 1945 Constitution of the Republic of Indonesia which consists of Article 1 paragraph (3), Article 27 paragraph (1) , Article 28 D paragraph (1), Article 28 G paragraph (1) and Article $28 \mathrm{H}$ paragraph (4) of the 1945 Constitution of the Republic of Indonesia. In essence, the petitioner in the review of the Fiduciary Law questioned the principles of legal certainty and legality of the arbitrariness of the recipient of the fiduciary right. (creditors) in the event of a breach of promise to carry out execution of the fiduciary guarantee object (James, 2020).

The Petitioner feels that the norms in these provisions only provide guarantees of human rights and protection to the recipient of fiduciary guarantees (creditors) without paying close attention to the rights of the debtor which should also be protected by law and law (James, 2020). Because in reality, due to the construction of Article 15 paragraph (2) and paragraph (3), which equates the position of a fiduciary guarantee certificate with a court decision in order for justice based on the one and only Godhead, it has caused arbitrariness and coercive action by creditors to the object. fiduciary guarantee under the control of the debtor.

Whereas according to the legal logic that should have been established if a fiduciary certificate is equated with a court decision that has obtained permanent legal force, then the procedure for executing the fiduciary object should also go through the same steps or at least the same as the court decision procedure with permanent legal force (incracht van gewijde) . Namely, by first submitting a request for execution to the head of the court as regulated in Article 196 HIR47 (Khifni, 2019). However, the fact is that before the Constitutional Court decision was read and it has general binding legal force (erga omnes).

Creditors often forcibly take every object of the fiduciary guarantee that is under the control of the debtor without any prior explanation to the court. When viewed at a glance, perhaps the intention of the creator of the Fiduciary Law wanted a simple, cheap, effective and efficient process to execute fiduciary guarantees. Because if in every execution of a fiduciary guarantee due to the existence of a wan achievement from the debtor, it must go through a court mechanism process, this activity will certainly hamper the creditor's economic activity because it has to go through a series of procedures in court (Ita, 2018).

Not to mention in terms of financing which must then be spent to take care of administration. So that in order to avoid that time consuming and costly amount of money, the executorial power in a fiduciary guarantee certificate is equated with a court decision having permanent legal force. Not only that, there is a time gap in executing the fiduciary collateral object of a defaulting debtor which will give the debtor the opportunity to take an action in bad faith (Nining, 2013).

This construction of thought, can be justified, but on the other hand, the existence of an all-powerful fiduciary guarantee certificate is equivalent to a court decision that can be executed directly by the holder or the recipient of the fiduciary guarantee (creditors) certainly opens up opportunities for abuse when there is no power relation to balance the action or the absence of an institution that can judge the validity or invalidity of the 
execution of the fiduciary security object due to default. As stated by Lord Acton, quoted by Zaeni, "power tends to corrupts, absolute power corrupts absolutely" this postulate can be translated simply that power tends to be abused and that great power without supervision of this power will certainly be abused (Zaeni, 2018 ).

The existence of the same power on a fiduciary guarantee certificate with a court decision that is legally enforceable still opens up loopholes for abuse by creditors. Such arbitrary action is certainly not an act that is permitted in law, even in the rules of civil law the purpose of civil law and civil procedure law, one of which is to prevent the existence of vigilantism (eigenrichting).

The imbalance of power relations between debtors and creditors over the object of fiduciary collateral is what the Constitutional Court tries to find a point of contact with in its Decision Number 18/PUUXVII/2019. This decision tries to protect debtors from bad faith creditor actions (bad faith) vis versa. This decision also protects creditors from bad faith debtors. The existence of an unbalanced power relationship between creditors and debtors in fiduciary guarantees violates the concept of rule of law.

Finally, on January 6, 2020, the Constitutional Court of the Republic of Indonesia issued Decision Number 18/PUU-XVII/2019 ("Constitutional Court Decision") in connection with a suit for judicial review of Article 15 Paragraph (2) and Paragraph (3) of Law Number 42 Year 1999 concerning Fiduciary Guarantee ("Law No. 42/1999"), among others are as follows (MK Decision, 2019):

"Declare Article 15 Paragraph (2) of Law Number 42 Year 1999 regarding Fiduciary Security as long as the phrase" executorial power "and the phrase" equal a court decision having permanent legal force "are contrary to the 1945 Constitution of the Republic of Indonesia and have no legal force. binding as long as it is not interpreted "against fiduciary security where there is no agreement on default (default) and the debtor. Objections to voluntarily handing over objects that become fiduciary guarantees, then all legal mechanisms and procedures in the execution of the Fiduciary Guarantee Certificate must be carried out and apply the same as the execution of court decisions that have permanent legal force.

State Article 15 Paragraph (3) of Law Number 42 Year 1999 concerning Fiduciary Security insofar as the phrase "breach of contract" contradicts the 1945 Constitution of the Republic of Indonesia and does not have binding legal force as long as it does not mean that "the existence of a breach of contract is not determined unilaterally by the creditor but on the basis of an agreement between the creditor and the debtor or on the basis of a legal remedy which determines that the default has occurred.

Declare the Elucidation of Article 15 Paragraph (2) of Law Number 42 of 1999 concerning Fiduciary Security as long as the phrase "executorial power" is contrary to the 1945 Constitution of the Republic of Indonesia and does not have binding legal force as long as it is not interpreted "against fiduciary security which is not There is an agreement regarding the default and the debtor objecting to voluntarily hand over the object which is the fiduciary guarantee, then all legal mechanisms and procedures in the execution of the Fiduciary Guarantee Certificate must be carried out and apply the same as the execution of court decisions which have permanent legal force.

As such, the Constitutional Court interprets the executorial power of the Fiduciary Guarantee depending on a situation, namely: 
a. If there has been an agreement regarding default (default) and the debtor does not object to voluntarily handing over the object which is the fiduciary guarantee, the Fiduciary Guarantee Certificate has the same executorial power as a court decision which has permanent legal force;

b. If the debtor is in default, the Fiduciary Recipient has the right to sell the object which is the object of fiduciary security on his own power, provided that on the basis of an agreement between the creditor and the debtor, or on the basis of legal remedies that determine that the default has occurred

In Decision Number 18/PUU-XVII/2019, as of January 6, 2020, the mechanism for the execution of the fiduciary object was changed by the Constitutional Court as long as it was not provided voluntarily by the debtor. Previously, the Fiduciary Law allowed creditors to execute the object of fiduciary collateral themselves, but since the Court's decision was made, to carry out the execution, creditors must submit an application to the District Court (PN) (Arya, 2020).

Implementation of direct execution by the creditor without going through the PN can be done if the debtor acknowledges a default or default in his agreement with the creditor. Article 15 paragraph (2) of the Fiduciary Law stipulates that a fiduciary guarantee certificate has the same executorial power as a court decision which has permanent legal force. The certificate contains the fiduciary giver and recipient, a description of the object, the value of the guarantee, and the value of the object, including the sentence 'For Justice Based on One Godhead' as stated in the court's decision. However, the material in the article does not provide justice and legal certainty for the debtor. Because creditors can at any time take or execute fiduciary guarantees without going through a court decision.

This action often creates arbitrariness and neglects the rights of the debtor. Furthermore, Article 15 paragraph (3) of Law 42/1999 states that fiduciary recipients have the right to sell objects that are the object of fiduciary security on their own power if the debtor fails to promise. The phrase "default" does not explain the reasons that have resulted in the debtor neglecting or denying his agreement with the creditor.

Default must be interpreted not only from the creditor's opinion but based on the agreement between the two or based on the existence of legal remedies which determine the occurrence of "default". Meanwhile, the phrase "default" in Article 15 paragraph (3) must be interpreted as a default not determined unilaterally by the creditor but on the basis of an agreement between the creditor and the debtor or on the basis of legal remedies that determine the occurrence of "default". The Constitutional Court's decision is a rectification of the unilateral abuses of creditors and debt collectors who can seize or control debtors and debtors at any time without legal protection.

\section{CONCLUSION}

Direct execution by creditors without going through the District Court can be done if the debtor admits that there is a default or default in his agreement with the creditor. Article 15 paragraph (2) of the Fiduciary Law stipulates that a fiduciary guarantee certificate has the same executorial power as a court decision which has permanent legal force. The certificate contains the fiduciary giver and recipient, a description of the object, 
the value of the guarantee, and the value of the object, including the sentence 'For Justice Based on One Godhead' as stated in the court's decision.

The applicant has the legal standing to conduct a judicial review of the Fiducia Law and in this case the Constitutional Court ruled that default must be interpreted not only from the creditor's opinion but on the basis of the agreement between the two or based on the existence of legal remedies that determine the occurrence of "default". Meanwhile, the phrase "default" in Article 15 paragraph (3) must be interpreted as a default not determined unilaterally by the creditor but on the basis of an agreement between the creditor and the debtor.

\section{REFERENCES}

Ade, A. dan Edia, H. (2009). Bank dan Lembaga Keuangan Bukan Bank. Jakarta Barat: PT. Macanan Jaya Cemerlang.

Agus, Y. H. (2014). Hukum Perjanjian: Asas Proporsionalitas Dalam Kontrak Komersial. Cet. IV Jakarta: Prenada Media.

Aprilianti. (2011). Perjanjian Sewa Guna Usaha antara Lesse dan Lessor. Fiat Justisia Jurnal Ilmu Hukum. ISSN: 1978-5186. 5(3), September-Desember 2011

Arya, W. D. (2020). Lembaga Jaminan Fidusia: Pasca Putusan Mahkamah Konstitusi Nomor 18/PUU-XVII/2019. Nagari Law Review. 3(2).

Ita, A. (2018). Perusahaan leasing dan Debt Collector dalam Penagihan Kredit Macet Kendaraan Debitur. Jurnal Hukum dan Keadilan. ISSN: 2338-4638. 2(8).

James, R. E. (2020). Eksekusi Objek Jaminan Fidusia Pasca Putusan Mahkamah Konstitusi Nomor 18/PUU-XVII/2019. 12(1).

Jatmiko, W. (2015). Perlindungan Hukum Bagi Kreditur pada Perjanjian Jaminan Fidusia. Jurnal Independent. Fakuktas Hukum Universitas Islam Lamongan. 7(3).

Joni, A. (2020). Rekonstruksi Pelaksanaan Eksekusi Jaminan Fidusia Pasca Putusan Mahkamah Konstitusi Nomor 18/PUU-XVII/2019. Eksekusi. 2(1).

Khifni, K. R. and Rian S. (2019). Tinjauan Hukum Terhadap Eksekusi Objek Jaminan Fidusia Tanpa Titel Eksekutorial Yang Sah. Refleksi Hukum Jurnal Ilmu Hukum. 4.

Khotibul, U. (2010). Hukum Lembaga Pembiayaan. Yogyakarta: Pustaka Yustisia.

M. Yahya, Harahap. (2005). Ruang Lingkup Permasalahan Eksekusi Bidang Perdata. Jakarta: Sinar Grafika.

M. Yasir. (2016). Aspek Hukum Jaminan Fidusia. Salam Jurnal Sosial \& Budaya Syari. Jakarta: UIN Syarif Hidayatullah Jakarta. 3(1).

Moch. Isnaeni. (2017). Pengantar Hukum Jaminan Kebendaan. Yogyakarta: LaksBang PRESSindo.

Munir, F. (2013). Hukum Jaminan Utang. Jakarta: PT Erlangga.

Nahrowi. (2013). Permasalahan Hukum Pembiayaan Leasing di Indonesia. Jurnal Cita Hukum. 1(1).

Nining, W. (2013). Sewa Guna Usaha (Leasing) dalam Perspektif Syariah. Jurnal Al-Amwal. ISSN: 2303-1573. 5(1).

Shavira, R. (2017). Penarikan Kendaraan Bermotor Oleh Perusahaan Pembiayaan Terhadap Debitur Yang Mengalami Kredit Macet (Wanprestasi) Dengan Jaminan Fidusia Ditinjau Dari Aspek Yuridis. Jurnal Ilmiah Fakultas Hukum. 6(2). 
Sri, S. (2014). Hukum Jaminan di Indonesia Pokok-Pokok Hukum Jaminan dan Jaminan Perorangan. Yogyakarta: Badan Pembinaan Hukum Nasional Departemen Kehakiman, Liberty.

Sugianto. (2014). Rekontruksi Perjanjian Fidusia atas Benda Bergerak yang didaftarkan Berdasarkan Nilai Keadilan. Jurnal Pembaharua Hukum 1(3).

Sunaryo. (2007). Hukum Lembaga Pembiayaan. Jakarta: Sinar Grafika.

Vera, R. S. (2020). Tinjauan Yuridis Terhadap Debt Collector Dan Leasing Pasca Putusan Mahkamah Konstitusi Nomor 18/PUU-XVII/2019. Gorontalo Law Review. 1(2).

Zaeni, A. (2018). Hukum Keperdataan dalam Perspektif Hukum Nasional, Perdata (BW), Hukum Islam, dan Hukum Adat. Depok: PT. Raja Grafindo. 